\title{
KETERBUKAAN INFORMASI PUBLIK DALAM PEMERINTAHAN TERBUKA MENUJU TATA PEMERINTAHAN YANG BAIK
}

(Public Information Disclosure in Open Government Towards Good Governance)

\section{Nunuk Febriananingsih, S.H., M.H.}

Analis Hukum pada Bidang Penelitian Budaya Hukum dan Masyarakat

Pusat Penelitian dan Pengembangan Sistem Hukum Nasional BPHN

\begin{abstract}
Abstrak
Kebebasan informasi merupakan hak asasi yang fundamental. Pengalaman selama ini menunjukkan bahwa informasi lembaga pemerintah dan non pemerintah dianggap sulit dijangkau masyarakat. Permasalahan yang diangkat dalam tulisan ini adalah bagaimana kesiapan lembaga-lembaga pemerintah dalam mengimplementasikan UU KIP dalam upaya mewujudkan tata pemerintahan yang baik. Dengan menggunakan metode penelitian hukum normatif diketahui bahwa Undang-Undang Nomor 14 Tahun 2008 tentang Keterbukaan Informasi Publik memberi jaminan kepada masyarakat untuk mengakses informasi dari badan publik, meskipun lembaga pemerintah belum siap mengimplementasikan UU KIP. $\mathrm{Hal}$ ini terlihat dari belum tersedianya informasi terkait dengan urusan tata kepemerintahan seperti kebijakan publik dan pelayanan publik. Untuk itu Pemerintah perlu segera mengimplementasikan UU KIP sesuai dengan yang diamanatkan oleh PP Nomor 61 Tahun 2010 tentang pelaksanaan UU KIP.
\end{abstract}

Kata kunci: keterbukaan informasi publik, pemerintahan yang baik, pemerintahan terbuka

\section{Abstract}

Freedom of information is a fundamental human right. Past experience shows that information and non-governmental agencies are considered hard to reach communities. Issues raised in this paper is how the readiness of government agencies in implementing the law is in an effort to realize good governance. By using the method of normative legal research note that the Act No. 14 of 2008 concerning Freedom of Information gives assurance to the public to access information from public bodies, although the government agency implementing the law is not yet ready. This is evident from the unavailability of information relating to the affairs of governance such as public policy and public service. For the Government should immediately implement in accordance with the law is mandated by the Government Regulation Number 61 Year 2010 concerning the implementation of the law is.

Keyword: public disclosure, good governance, open government 


\section{A. Pendahuluan}

Sejak Tahun 1946 Majelis Umum PBB mengadopsi Resolusi 59 (1) yang menyatakan bahwa "Kebebasan informasi adalah hak asasi yang fundamental dan merupakan tanda dari seluruh kebebasan yang akan menjadi titik perhatian PBB". ${ }^{1}$ Oleh sebab itu hak atas informasi kemudian menjadi salah satu hak yang diakui secara internasional, yang diatur dalam Pasal 19 Deklarasi Universal HAM PBB yang menyatakan bahwa:

"Setiap orang mempunyai hak atas kebebasan mengemukakan pendapat dan gagasan; hak ini mencakup hak untuk memegang pendapat tanpa campur tangan, dan mencari, menerima dan menyebarkan informasi dan gagasan melalui media apapun tanpa mempertimbangkan garis batas negara."

Indonesia pun sudah memberikan pengakuan atas hak informasi sebagaimana diatur dalam konstitusi Perubahan Kedua Undang-Undang Dasar Negara Republik Indonesia Tahun 1945 (UUD NRI Tahun 1945) Pasal 28F yang menyatakan bahwa:

"Setiaporangberhakuntukberkomunikasi dan memperoleh informasi untuk mengembangkan pribadi dan lingkungan sosialnya, serta berhak untuk mencari, memperoleh, memiliki dan menyimpan informasi dengan menggunakan segala jenis saluran yang tersedia"

Dengan demikian, maka hak atas informasi tidak saja merupakan hak asasi melainkan juga hak konstitusional rakyat
Indonesia. Esensi dari pengakuan ini adalah bahwa hak atas informasi sebenarnya merupakan hak yang melekat pada diri setiap manusia baik sebagai warga negara maupun sebagai pribadi.

Undang-Undang Nomor 14 Tahun 2008 tentang Keterbukaan Informasi Publik (UU KIP) telah disahkan oleh Dewan Perwakilan Rakyat (DPR) sejak 30 April 2008 dan mulai berlaku setelah dua tahun diundangkan, tepatnya 30 April 2010. UU KIP adalah undang-undang yang memberikan jaminan terhadap semua orang untuk memperoleh informasi publik dalam rangka mewujudkan serta meningkatkan peran serta aktif masyarakat dalam penyelenggaraan negara, baik pada tingkat pengawasan pelaksanaan penyelenggaraan negara maupun pada tingkat pelibatan masyarakat dalam proses pengambilan kebijakan publik.

UU KIP menjadi landasan operasional yang memberi jaminan terbukanya akses informasi bagi masyarakat secara luas dari lembaga-lembaga negara, lembaga publik non pemerintah dan perusahaan-perusahaan publik yang mendapat alokasi dana dari Anggaran Pendapatan Belanja Negara (APBN), Anggaran Pendapatan Belanja Daerah (APBD), bantuan luar negeri dan dari himpunan dana masyarakat. Dengan demikian, keberadaan UU KIP semakin menegaskan bahwa akses masyarakat terhadap informasi merupakan hak asasi manusia yang diakui oleh konstitusi UUD NRI Tahun 1945.

Toby Mendel, Freedom of Information as an Internationally Protected Human Right, article 19. (www.article19. org, diakses pada tanggal 07 Januari 2012). 


\section{$\mathrm{R}^{\text {juknal }}$ ECHSVINDING}

Secara umum, UU KIP diharapkan akan membangun keterbukaan informasi di lembaga pemerintah dan non pemerintah yang selama ini dianggap sulit dijangkau masyarakat. Secara khusus, eksistensi regulasi mengenai keterbukaan informasi publik dapat mendorong suatu masyarakat menjadi lebih demokratis dengan memungkinkan adanya akses masyarakat terhadap informasi yang dimiliki pemerintah baik pemerintah pusat, pemerintah daerah maupun lembaga-lembaga publik lain seperti lembaga pendidikan dan lembaga kesehatan, misalnya rumah sakit. Oleh sebab itu UU KIP mendukung transparansi informasi di seluruh lembaga pemerintah yang merupakan salah satu syarat penyelenggaraan pemerintahan demokratis yang diharapkan membawa perubahan paradigma pemerintah dalam mengelolainformasipublikdaripemerintahan yang tertutup menuju pemerintahan yang terbuka. Jika sebelum UU KIP diundangkan, paradigmanya adalah seluruh informasi publik adalah rahasia kecuali yang terbuka, namun setelah UU KIP diundangkan, paradigma tersebut bergeser menjadi seluruh informasi publik adalah terbuka untuk di akses masyarakat kecuali yang dikecualikan/ rahasia dengan pengencualian yang terbatas (Maximum Access Limited Exemption / MALE).

\section{B. Rumusan Masalah}

1. Bagaimana materi muatan dalam Undang-Undang Keterbukaan Informasi Publik?

2. Sejauh mana kesiapan lembagalembaga pemerintah dalam mengimplementasikan UU KIP?

3. Bagaimana implementasi keterbukaan informasi publik dalam pemerintahan terbuka (open government) menuju terciptanya tata pemerintahan yang baik (good governance)?

\section{Metode Penelitian}

Metode pendekatan yang digunakan dalam penelitian ini adalah penelitian hukum normatif. Penelitian hukum normatif yaitu berupa penelitian kepustakaan (library research) untuk memperoleh data-data berupa dokumen hukum baik yang berupa peraturan perundang-undangan, Keputusan Komisi Informasi, Jurnal, makalah dan buku-buku yang berkaitan dengan pokok permasalahan yang diteliti. ${ }^{2}$

Penelitian kepustakaan (library research) ini dimaksudkan untuk mendapatkan data sekunder, berupa bahan-bahan hukum yang meliputi yaitu: ${ }^{3}$

1. bahan hukum primer, peraturan perundang-undangan yang berlaku di Indonesia yang terkait dengan penulisan ini antara lain UUD NRI tahun 1945, UU KIP, Peraturan Pemerintah (PP) No. 61

Soerjono Soekanto dan Sri Mamudji, Penelitian Hukum Normatif Suatu Tinjauan Singkat, (Jakarta: Rajawali Press, 1990), hal. 15.

Sri Mamudji, dkk, Metode Penelitian dan Penulisan Hukum, (Jakarta: Badan Penerbit FH UI, 2005), hal. 28. 
Tahun 2010 tentang Pelaksananaan UU KIP, Keputusan Komisi Informasi No. 1 Tahun 2010 tentang Standar Layanan Informasi Publik, Keputusan Komisi Informasi No. 2 Tahun 2010 tentang Prosedur Penyelesaian Sengketa Informasi serta peraturan perundangundangan lainnya sebagai bahan pembanding dalam penulisan ini.

2. bahan hukum sekunder, yaitu bahanbahan hukum yang memberikan penjelasan lebih lanjut pada bahan hukum primer. Bahan hukum sekunder yang digunakan dalam penelitian ini berupa bahan hukum sekunder yang terdiri dari buku-buku, jurnal-jurnal, artikel, laporan penelitian yang sudah ada sebelumnya, internet dan berbagai publikasi ilmiah dan referensi yang berkaitan dengan permasalahan yang diteliti.

3. bahan hukum tertier, yakni bahanbahan yang memberi petunjuk maupun penjelasan terhadap bahan hukum primer dan sekunder antara lain kamus hukum, kamus bahasa Indonesia, buku pegangan dan sebagainya yang ada relevansinya dengan permasalahan penelitian.

Spesifikasi penelitian ini adalah deskriptif analitis, yakni menggambarkan peraturan yang berlaku seperti UU KIP dan kemudian dianalisa secara yuridis sesuai dengan perkembangan hukum yang berlaku. Analisa data dilakukan secara kualitatif normatif, yakni dengan cara menjabarkan dengan kalimat-kalimat sehingga diperoleh bahasan atau paparan yang sistematis agar mudah dimengerti serta digunakan untuk melakukan analisis dengan mengkaji data hasil penelitian berdasarkan teori dan dokumen hukum. Dengan analisa tersebut diharapkan pada akhirnya dapat mengungkapkan masalah yang terjadi secara rinci dan menghasilkan suatu kesimpulan. ${ }^{4}$

\section{Pembahasan}

\section{Materi Muatan Undang-Undang Keterbukaan Informasi Publik (UU KIP)}

Salah satu elemen penting dalam mewujudkan penyelenggaraan negara yang terbuka adalah hak publik untuk memperoleh informasi sesuai dengan peraturan perundang-undangan. Hak atas informasi menjadi sangat penting karena makin terbuka penyelenggaraan negara untuk diawasi publik, penyelenggaraan negara tersebut makin dapat dipertanggungjawabkan. Hak setiap orang untuk memperoleh informasi juga relevan untuk meningkatkan kualitas pelibatan masyarakat dalam proses pengambilan keputusan publik. Partisipasi atau pelibatan masyarakat tidak banyak berarti tanpa jaminan keterbukaan informasi publik. $^{5}$

\section{Asiam Sumhudi, 1986, hal. 45-47}

Republik Indonesia, Undang-Undang Nomor 14 Tahun 2008 tentang Keterbukaan Informasi Publik, ditetapkan di Jakarta tanggal 30 April 2008, Lembaran Negara RI Nomor 61, tahun 2008 dan Tambahan Lembaran Negara RI Nomor 4846 Tahun 2008, bagian Penjelasan Umum. 
UU KIP telah diundangkan pada tanggal 30 April 2008 dalam Lembaran Negara Republik Indonesia Tahun 2008 Nomor 61 dan Tambahan Lembaran Negara Republik Indonesia Nomor 4846 dan mulai berlaku efektif sejak 2 tahun diundangkan yaitu tanggal 30 April 2010. UU KIP yang terdiri dari 14 Bab 64 Pasal ini menghendaki tersedianya informasi secara lengkap, tersusun rapi, dan terpusat pada satu institusi badan informasi publik. Dengan demikian informasi yang dibutuhkan menjadi mudah diakses baik oleh pegawai pemerintah maupun masyarakat dan otomatis menghemat biaya dan mengefisienkan waktu kerja yang diperlukan ketika menelusuri dan mencari informasi yang sebelumnya terserak atau tidak tertata dengan baik. Hal ini sangat penting demi meningkatkan hubungan baik antara instansi pemerintah dengan masyarakat. UU KIP ini mengamanatkan empat peraturan turunan yaitu:
a. PP tentang masa retensi (masa berlakunya kerahasiaan);
b. PP tentang ganti rugi;
c. Peraturan Komisi Informasi tentang standar layanan informasi;
d. Peraturan Komisi Informasi tentang prosedur penyelesaian sengketa;

Keberadaan UU KIP sangat penting sebagai landasan hukum yang berkaitan dengan (1) hak setiap orang untuk memperoleh informasi; (2) kewajiban badan publik menyediakan dan melayani permintaan informasi secara cepat, tepat waktu, biaya ringan/proporsional dan cara sederhana; (3) pengecualian bersifat ketat dan terbatas; (4) kewajiban badan publik untuk membenahi sistem dokumentasi dan pelayanan informasi. ${ }^{6}$

Tujuan dan asas keterbukaan informasi publik UU KIP pada dasarnya adalah memberikan arah, landasan, acuan dan jaminan tentang pemenuhan hak publik atas informasi yang didasarkan pada ketentuan peraturan perundang-undangan. UU KIP ini dimaksudkan untuk mewujudkan penyelenggaraan negara yang baik, transparan, efektif dan efisien, akuntabel dan dapat dipertanggungjawabkan. ${ }^{7}$

Sebagaimana termaktub dalam Pasal 2 UU KIP, asas UU KIP adalah sebagai berikut: Pertama, setiap informasi publik bersifat terbuka dan dapat di akses oleh setiap pengguna informasi publik; Kedua, informasi publik yang dikecualikan bersifat ketat dan terbatas; Ketiga, setiap informasi publik harus dapat diperoleh setiap pemohon informasi publik dengan cepat dan tepat waktu, biaya ringan, dan cara yang sederhana; Keempat, informasi publik yang dikecualikan bersifat rahasia sesuai undang-undang, kepatuhan dan kepentingan umum, didasarkan pada pengujian tentang konsekuensi yang timbul apabila suatu informasi diberikan kepada masyarakat, serta setelah dipertimbangkan 
dengan seksama bahwa menutup informasi publik dapat melindungi kepentingan yang lebih besar daripada membukanya dan sebaliknya.

Adapun tujuan dari UU KIP tergambar pada Pasal 3, yaitu:

a. menjamin hak warga negara untuk mengetahui rencana pembuatan kebijakan publik, program kebijakan publik, dan proses pengambilan keputusan publik, serta alasan pengambilan suatu keputusan publik;

b. mendorong partisipasi masyarakat dalam proses pengambilan kebijakan publik;

c. meningkatkan peran aktif masyarakat dalam pengambilan kebijakan publik dan pengelolaan Badan Publik yang baik;

d. mewujudkan penyelenggaraan negara yang baik, yaitu transparan, efektif dan efisien, akuntabel serta dapat dipertanggungjawabkan;

e. mengetahui alasan kebijakan publik yang mempengaruhi hajat hidup orang banyak;

f. mengembangkan ilmu pengetahuan dan mencerdaskan kehidupan bangsa; dan/ atau

g. meningkatkan pengelolaan dan pelayanan informasi di lingkungan badan publik untuk menghasilkan layanan informasi yang berkualitas
Dalam asas dan tujuan UU KIP, tampak jelas bahwa UU KIP memberikan jaminan atas hak warga negara atas informasi. Sejalan dengan hal tersebut, sudah sewajarnya jika terdapat batasan-batasan tertentu atas informasi yang dikecualikan atau tidak dapat disampaikan kepada publik. ${ }^{8}$

Badan publik yang di maksud dalam UU KIP adalah Lembaga Eksekutif (Kementerian Negara, Lembaga Negara, Lembaga Pemerintah Non Kementerian), Lembaga Legislatif (Sekretariat DPR, DPD, DPRD), Lembaga Yudikatif (MK, MA, Kejaksaan Agung, Komisi Yudisial), BUMN, BUMD, Komisi Negara, Komisi Independen, Parpol, LSM, Yayasan, Ormas. Dengan demikian dapat dikatakan bahwa tidak ada lembaga pemerintah maupun non pemerintah seperti yang di maksud dalam UU KIP terbebas dari kewajiban memberikan informasi kepada publik.

Secara normatif, hak dan kewajiban pemohon dan pengguna informasi publik dan badan publik sebagai penyedia informasi telah diatur dalam Pasal 4-8 UU KIP secara rinci, namun terdapat aspek-aspek yang perlu diperhatikan antara lain: Pertama, alasan permintaan informasi, keharusan mengemukakan alasan untuk meminta informasi publik akan menjadi hambatan dalam penyediaan informasi karena alasanalasan itu tidak bersifat universal; Kedua, batasan melanggar hak-hak pribadi, hal ini akan menimbulkan multi tafsir tergantung

8 Ahmad M. Ramli, KIP dan Good Governance, Makalah disampaikan pada Seminar Sosialisasi UU KIP di Jakarta, Tahun 2009, hal. 3. 
perspektif pribadi yang bersangkutan; Ketiga, batasan tentang rahasia jabatan. Perlu batasan yang jelas tentang hal-hal yang berkaitan dengan rahasia jabatan, sebab akan menimbulkan dualisme persepsi yang dapat berakibat pada ketidakpercayaan pada lembaga dalam memberikan informasi kepada publik.

Informasi yang wajib disediakan dan diumumkan secara berkala diatur dalam Pasal 9 UU KIP. Informasi tersebut harus disediakan/diumumkan secara rutin, teratur dan dalam jangka waktu tertentu setidaknya setiap 6 bulan sekali. Penyebaran informasi disampaikan dengan cara yang mudah dijangkau masyarakat dan dalam bahasa yang mudah dipahami, meliputi: informasi yang berkaitan dengan badan publik (seperti profil, kedudukan, kepengurusan, maksud dan tujuan didirikannya badan publik tersebut); informasi yang berkaitan dengan kegiatan dan kinerja badan publik; informasi tentang laporan keuangan dan informasi lain yang diatur dalam peraturan perundangundangan.

Informasi yang harus diumumkan secara serta merta diatur dalam Pasal 10, dimana informasi ini wajib diumumkan tanpa penundaan. Informasi yang di maksud adalah informasi yang menyangkut ancaman terhadap hajat hidup orang banyak dan ketertiban umum, misalnya informasi tentang bencana, kerusuhan massal dan lain-lain.

Informasi yang wajib tersedia setiap saat diatur dalam Pasal 11 UU KIP. Informasi ini sifatnya wajib dan rutin disediakan badan publik, namun untuk memperolehnya harus dilakukan dengan mengajukan permintaan. Yang termasuk dalam kategori informasi ini antara lain: daftar seluruh informasi dalam penguasaan badan publik; keputusan badan publik dan pertimbangannya; kebijakan badan publik dan dokumen pendukungnya; rencana proyek dan anggaran tahunannya; perjanjian badan publik dengan pihak ketiga, informasi dalam pertemuan yang bersifat terbuka untuk umum; prosedur kerja yang berkaitan dengan layanan publik; laporan layanan akses informasi dan informasi lain yang telah dinyatakan terbuka untuk diakses publik berdasarkan putusan sengketa informasi publik.

Disamping berbagai jenis informasi dalam UU KIP tersebut diatas yang wajib disediakan oleh badan publik, terdapat informasi yang dikecualikan. Pasal 17 UU KIP menyebutkan kategori informasi yang dikecualikan, yaitu:

a. Informasi publik yang apabila dibuka dan diberikan kepada pemohon informasi publik dapat menghambat proses penegakan hukum;

b. Informasi publik yang apabila dibuka dan diberikan kepada pemohon informasi publik dapat mengganggu kepentingan perlindungan hak atas kekayaan intelektual dan perlindungan dari persaingan usaha tidak sehat;

c. Informasi publik yang apabila dibuka dan diberikan kepada pemohon informasi publikdapat membahayakan pertahanan dan keamanan negara; 
d. Informasi publik yang apabila dibuka dan diberikan kepada pemohon informasi publik dapat mengungkapkan kekayaan alam Indonesia;

e. Informasi publik yang apabila dibuka dan diberikan kepada pemohon informasi publik dapat merugikan ketahanan ekonomi nasional;

f. Informasi publik yang apabila dibuka dan diberikan kepada pemohon informasi publik dapat merugikan kepentingan hubungan luar negeri;

g. Informasi publik yang apablila dibuka dapat mengungkapkan akta otentik yang bersifat pribadi dan kemauan terakhir ataupun wasiat seseorang;

h. Informasi publik yang apabila dibuka dan diberikan kepada pedoman informasi publik dapat mengungkap rahasia pribadi, memorandum atau surat-surat antar badan publik atau intra badan publik, yang menurut sifatnya dirahasiakan kecuali atas putusan Komisi Informasi atau pengadilan;

i. Informasi yang tidak boleh diungkapkan berdasarkan Undang-Undang.

Informasi publik dikecualikan apabila dipertimbangkan jika membuka informasi publik tersebut dapat menimbulkan konsekuensi sebagaimana diatur dalam Pasal 17 dan dengan menutup informasi dapat melindungi kepentingan yang lebih besar daripada membukanya. Namun demikian, akses terhadap informasi yang dikecualikan tetap dapat dilakukan sepanjang informasi yang dikecualikan tersebut menyangkut data pribadi seseorang (privacy) dengan ketentuan pihak yang rahasianya diungkap memberikan persetujuan tertulis dan/atau pengungkapan yang terkait dengan posisi seseorang dalam jabatan-jabatan publik. Selain terkait dengan privacy seseorang, informasi publik yang dikecualikan terkait dengan keuangan negara juga bisa diakses dengan mengajukan permintaan izin kepada Presiden dengan ketentuan:

a. Perkara pidana diajukan oleh Kapolri, Jaksa Agung, Ketua Mahkamah Agung, Ketua Komisi Pemberantasan Korupsi, dan/atau pimpinan lembaga negara penegak hukum lainnya yang diberi wewenang oleh undang-undang.

b. Perkara perdata yang berkaitan dengan keuangan atau kekayaan negara diajukan oleh Jaksa Agung sebagai pengacara negara.

Namun demikian, dengan mempertimbangkan kepentingan pertahanan dan kemanan negara juga kepentingan umum, presiden dapat menolak permintaan informasi yang dikecualikan.

Badan publik wajib mempunyai standar prosedur operasional tata cara pengecualian informasi. Standar prosedur operasional tersebut setidaknya memuat tentang tata cara pengecualian informasi di internal publik, klasifikasi informasi yang dikecualikan serta tindakan terhadap masing-masing klasifikasi tersebut, alasan pengecualian informasi berdasarkan Pasal 17 UU KIP, tata cara permintaan izin untuk membuka informasi mengenai akta otentik yang bersifat pribadi 
dan informasi pribadi lainnya, tata cara membuka informasi yang dikecualikan dalam rangka penegakan hukum. Badan Publik wajib meninjau standar prosedur operasional tersebut secara berkala setidaknya satu tahun sekali dan menyampaikan hasilnya kepada Komisi Informasi.

Komisi Informasi (KI) diatur dalam UU KIP Bab VII, Pasal 23 - 50. Komisi Informasi adalah lembaga mandiri yang berfungsi menjalankan UU KIP dan peraturan pelaksanaannya. Komisi Informasi terdiri atas Komisi Informasi Pusat, Komisi Informasi Provinsi dan jika dibutuhkan Komisi Informasi Kabupaten/Kota. Komisi ini juga bertugas untuk menetapkan petunjuk teknis standar layanan informasi publik. Berkaitan dengan kewenangan ini KI Pusat sudah menerbitkan Peraturan Komisi Informasi Nomor 1 Tahun 2010 tentang Standar Layanan Informasi Publik. Selain itu, KI juga mempunyai wewenang untuk membuat mekanisme penyelesaian sengketa informasi publik. Berkaitan dengan kewenangan ini KI Pusat sudah mengeluarkan Peraturan Komisi Informasi Nomor 2 Tahun 2010 tentang Prosedur Penyelesaian Sengketa Informasi Publik. Dalam hal kewenangan untuk menyelesaikan sengketa informasi publik, tugas Komisi Informasi baik di pusat maupun provinsi adalah menerima, memeriksa dan memutus permohonan penyelesaian sengketa informasi publik melalui mediasi dan/atau ajudikasi non-litigasi. Yang dimaksud dengan Sengketa Informasi Publik adalah sengketa yang terjadi antara badan publik dan pengguna informasi publik yang berkaitan dengan hak memperoleh dan menggunakan informasi berdasarkan peraturan perundang-undangan. Mediasi adalah penyelesaian sengketa informasi publik antara para pihak melalui bantuan mediator komisi informasi. Sedangkan Ajudikasi adalah proses penyelesaian sengketa informasi publik antara para pihak yang diputus oleh Komisi Informasi.

Menurut data yang diperoleh dari KI Pusat sejak Juli 2010 hingga Maret 2011 terdapat 224 perkara. Dari jumlah itu tidak semua ditangani KI Pusat. Data hingga Desember 2010 menunjukkan 11 permohonan penyelesaian sengketa informasi bukan kewenangan KI Pusat, sehingga dilimpahkan ke KI Provinsi; 22 sengketa informasi selesai melalui mediasi; 7 sengketa informasi selesai melalui ajudikasi; 65 sengketa informasi dalam proses mediasi; dan 38 sengketa informasi dalam proses analisis Majelis Pemeriksaan Pendahuluan (MPP). Sisanya, perkara tersebut dinyatakan tidak layak menjadi sengketa informasi. Pada tahun 2010 ada 17 perkara yang dinyatakan tidak layak, sedangkan pada Januari - Maret 2011 sudah mencapai 29 perkara. $^{9}$

9 Komisi Informasi, Laporan 1 Tahun Implementasi UU KIP, April Tahun 2011. 


\section{R duknal HTSVINDING}

Jumlah Permohanan Sengketa Informasi

(Juli 2010-Maret 2011)

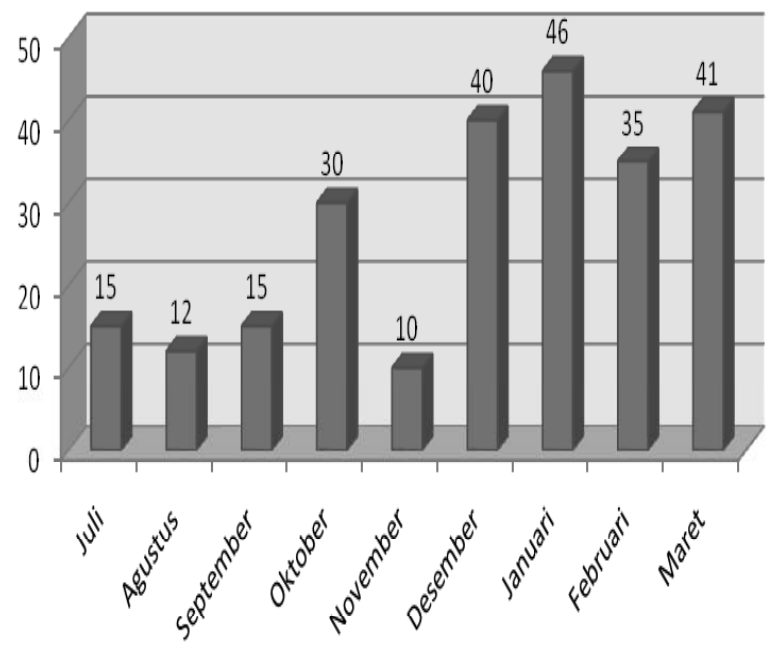

Sumber: www.komisiinformasi.go.id, diakses tanggal 07 Januari 2012.

Dari sisi kualifikasi pemohon, mayoritas permohonan sengketa informasi yang ditangani KI Pusat diajukan oleh individu WNI (56\%), Badan Hukum (42\%) dan Kelompok Orang $(2 \%){ }^{10}$

Sengketa berdasarkan Kategori Pemohon Tahun 2010

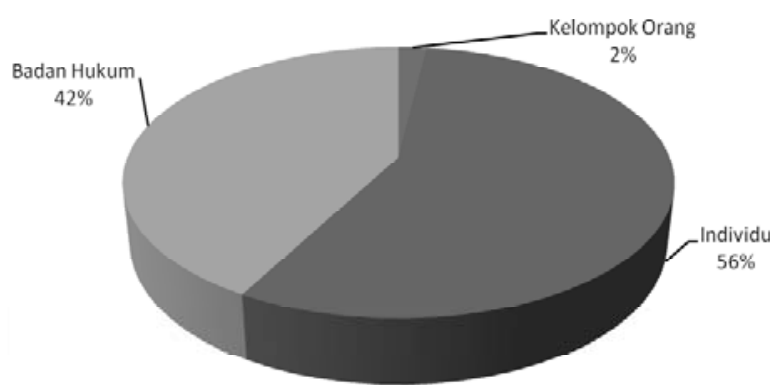

Sumber: www.komisiinformasi.go.id, diakses tanggal 07 Januari 2012.
Dari sisi kualifikasi informasi, informasi yang paling banyak diminta adalah berkaitan dengan informasi anggaran dan keuangan badan publik dan Daftar Informasi Publik. Dalam rangka mendorong keterbukaan informasi anggaran dan keuangan di semua Badan Publik, KI Pusat sudah menyampaikan Surat Edaran Nomor 1 Tahun 2011 yang pada intinya membuka informasi RKA-KL dan DIPA Badan Publik. ${ }^{11}$

Dalam pelaksanaan pelayanan informasi publik, tidak tertutup kemungkinan terjadi kesalahpahaman antara pemohon dan pemberi informasi publik. Kesalahpahaman ini dapat berujung pada sengketa informasi publik antara pemohon dan pemberi informasi publik. Penyelesaian sengketa dapat dilakukan dengan cara diajukan ke Komisi Informasi, dengan tahapan mediasi (sifatnya final dan kesepakatan mengikat) dan dengan ajudikasi non litigasi. Data yang diperoleh dari Komisi Informasi Pusat, dalam proses penyelesaian sengketa KI Pusat mendorong agar diselesaikan kedua belah pihak melalui mediasi secara sukarela. Menurut data, sepanjang Tahun 2010-2011 jumlah sengketa yang berhasil di mediasi mencapai 21 perkara (9,37\%), sedangkan yang di putus melalui ajudikasi mencapai 7 perkara. Selebihnya masih dalam proses mediasi dan administrasi. ${ }^{12}$ 
Jenis Informasi yang Disengketakan Tahun 2010

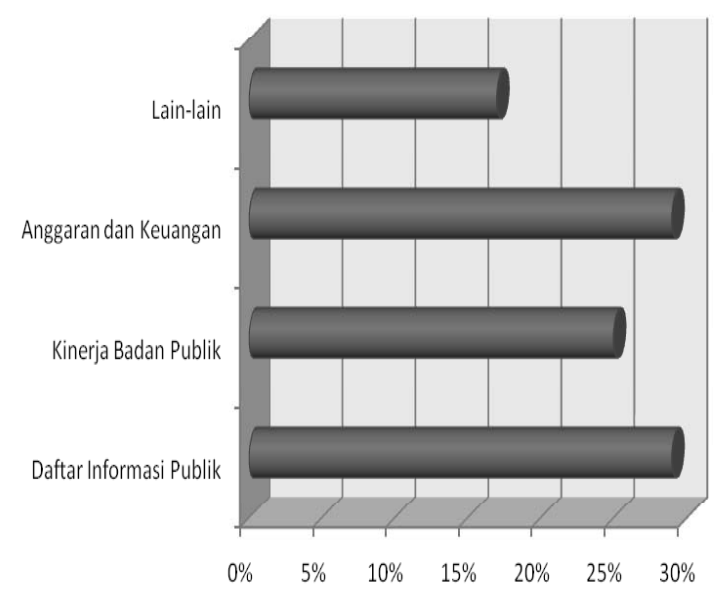

Sumber: www.komisiinformasi.go.id, diakses tanggal 07 Januari 2012

Selain mediasi dan ajudikasi non litigasi, dimungkinkan penyelesaian sengketa informasi melalui gugatan pengadilan yang diatur dalam Pasal 47-48 UU KIP. Pengajuan gugatan dilakukan melalui Pengadilan Tata Usaha Negara (PTUN) apabila yang digugat adalah Badan Publik Negara dan ke Pengadilan Negeri apabila yang digugat adalah Badan Publik Bukan Negara.

\section{Kesiapan Lembaga Pemerintah Dalam Implementasi UU KIP}

Jika dilihat dari konteks hubungan antara pemerintah dan warganegaranya, secara garis besar implikasi penerapan UU KIP tersebut melekat pada dua pihak, yaitu penyelenggara pemerintahan dan masyarakat atau publik. Pada pihak penyelenggara pemerintahan, ada beberapa implikasi penerapan UU KIP, seperti kesiapan lembaga pemerintah untuk mengklasifikasikan informasi publik menjadi informasi yang wajib disediakan dan diumumkan secara berkala, informasi yang wajib diumumkan serta merta, dan informasi yang wajib disediakan. Implikasi lain bagi pemerintah pada saat UU KIP diterapkan nantinya adalah semua urusan tata kepemerintahan berupa kebijakankebijakan publik, baik yang berkenaan dengan pelayanan publik, pengadaan barang dan jasa pemerintah, penyusunan anggaran pemerintah, maupun pembangunan harus diketahui oleh publik, termasuk juga isi keputusan danalasan pengambilan keputusan kebijakan publik serta informasi tentang kegiatan pelaksanaan kebijakan publik tersebut beserta hasil-hasilnya harus terbuka dan dapat diakses oleh publik. Sehingga ada konsekuensi bahwa aparatur pemerintahan atau badan publik harus bersedia secara terbuka dan jujur memberikan informasi yang dibutuhkan publik, hal seperti ini bagi sebagian atau mungkin seluruhnya dari aparat pemerintah atau badan publik merupakan hal yang belum atau tidak terbiasa untuk dilakukan. Tetapi implikasi ini beserta konsekuensinya tetap harus dihadapi sejalan dengan penerapan UU KIP.

Implikasi penerapan UU KIP terhadap masyarakat atau publik adalah terbukanya akses bagi publik untuk mendapatkan informasi yang berkaitan dengan kepentingan publik, terbukanya akses bagi publik untuk berpartisipasi aktif dalam proses pembuatan kebijakan publik, termasuk didalamnya akses untuk pengambilan keputusan dan mengetahui alasan pengambilan keputusan yang berkaitan dengan kepentingan publik. Kemudian implikasi yang dipandang sangat 
penting adalah dengan adanya penerapan UU KIP ini daya kritis masyarakat atau publik terhadap kinerja penyelenggaraan pemerintahan terutama pelayanan publik semakin meningkat dan diperkirakan tingkat penilaian atau pengaduan masyarakat atau publik terhadap kualitas layanan publik juga semakin meningkat.

Implikasi lain sejalan dengan meningkatnya daya kritis masyarakat, adalah peningkatan pengetahuan masyarakat mengenai hak-hak mereka dalam pelayanan publik yang disediakan oleh lembaga pemerintah. Sehingga apabila suatu saat terjadi ketimpangan atau permasalahan dalam pelayanan publik, maka akan banyak pengaduan masyarakat berkaitan dengan kualitas pelayanan publik tersebut. Meningkatnya pengetahuan masyarakat mengenai proses penyelenggaraan pemerintahan, juga merupakan implikasi yang akan dihadapi dalam penerapan UU KIP. Dan hal tersebut dapat meningkatkan minat dan keinginan masyarakat untuk berperan serta dan berpartisipasi dalam proses penyelenggaraan pemerintahan sesuai dengan kapasitas masing-masing. Dengan melihat berbagai implikasi yang telah disebutkan di atas baik yang dihadapi oleh masyarakat maupun penyelenggara pemerintahan, makatimbul suatu pertanyaan sejauh mana kesiapan lembaga pemerintah dalam mengantisipasi berbagai implikasi tersebut, paling tidak adalah selama satu tahun sejak UU KIP efektif diterapkan ada langkah-langkah baik itu beberapa kebijakan maupun penguatankelembagaan pemerintah daerah untuk meminimalkan benturan yang terjadi akibat implikasi penerapan UU KIP.

UU KIP jika diterapkan akan banyak memberikanmanfaatdalampenyelenggaraan pemerintahan. Manfaat tersebut antara lain: ${ }^{13}$

a. dapat mengurangi tingkat korupsi, sebab semakin tinggi akses publik terhadap laporan keuangan maka semakin rendah tingkat korupsi, demikian sebaliknya;

b. memperoleh indikasi dini adanya praktek mal administrasi dan tindak pidana korupsi, efisiensi anggaran. Di Jepang, UU KIP diusulkan sejak tahun 1960 oleh masyarakat, dan baru disahkan Law Concerning Access to Information (UU tentang Akses terhadap Informasi yang dikuasai Badan Administratif); di tahun 1995 anggaran jamuan 23,6 milyar yen, sementara pada tahun 1997 hanya 12 milyar yen di setiap provinsi. (disini terjadi efisiensi 58\%);

c. membukapeluang partisipasimasyarakat dalam mengawasi penyelenggaraan negara dan pelayanan publik;

d. bagi badan publik, mendapatkan umpan balik dari masyarakat tentang kinerja badan publik;

e. Bagi masyarakat, memperoleh jaminan kepastian hukum atas hak untuk memperoleh informasi publik dan

13 Usman Abdhali Watik, Implikasi UU Nomor 14 Tahun 2008 tentang Keterbukaan Informasi Publik terhadap Peningkatan Pelayanan Publik, (Surabaya: Universitas Kristen Petra, 26 Juli 2010), hal. 3-5. 
terhindar dari perlakuan sewenangwenang dari aparatur negara.

Dalam rangka implementasi tersebut, langkah awal yang harus dilakukan untuk kesiapan pemerintahan dalam penerapan UU KIP adalah sesuai amanat UU KIP. Selama 2 (dua) tahun sejak diundangkannya UU KIP telah dipersiapkan pula perangkat peraturan perundang-undangan dibawahnya sebagai peraturan pelaksananya. Komisi Informasi di bentuk sebagai amanat UU KIP. Setelah dibentuknya Komisi Informasi baik di tingkat pusat, provinsi dan jika dibutuhkan di bentuk pula KI di tingkat Kabupaten/Kota, sebagai peraturan pelaksana UU KIP dan sesuai dengan amanat Pasal 20 ayat (2) dan Pasal 58 UU KIP, Pemerintah menerbitkan Peraturan Pemerintah (PP) Nomor 61 Tahun 2010 tentang Pelaksanaan Undang-Undang Nomor 14 Tahun 2008 tentang Keterbukaan Informasi Publik yang diundangkan pada tanggal 23 Agustus 2010 dalam LNRI Tahun 2010 Nomor 99.

Dalam rangka mengimplementasikan UU KIP di lingkungan lembaga pemerintah dibutuhkan beberapa tambahan struktur, infrastruktur dan staf yang secara khusus mengelola dan memberi pelayanan informasi. Namun demikian, struktur yang akan di bentuk harus sederhana, efisien dan ramping, sehingga permintaan informasi tidak melalui jenjang birokrasi yang berbelitbelit dan memakan waktu yang lama.

Dalam PP Pelaksanaan UU KIP pada Bab IV Pasal 12-15 telah mengatur tentang Pejabat Pengelola Informasi dan Dokumentasi (PPID).
Mengingat informasi biasanya dikelola oleh bidang hubungan masyarakat (humas) yang ada di beberapa lembaga pemerintah, maka sering muncul usulan agar humas diperluas fungsi dan perannya sehingga mencakup bidang pelayanan informasi publik. Hal ini dimungkinkan berdasarkan ketentuan Pasal 21 ayat (2) PP Pelaksanaan UU KIP, dimana dikatakan bahwa dalam hal PPID belum ditunjuk, tugas dan tanggung jawab PPID dapat dilakukan oleh unit atau dinas di bidang informasi, komunikasi, dan/atau kehumasan. Namun demikian, PPID sudah harus ditunjuk paling lama 1 (satu) tahun terhitung sejak PP ini diundangkan sebagaimana di maksud dalam Pasal 21 ayat (1).

Jadi dapat disimpulkan bahwa penunjukan PPID sifatnya adalah wajib (mandatory). Hal ini memang sudah sesuai, sebab bidang humas memiliki tugas dan fungsi yang berbeda dari pelayanan informasi publik. Keduanya memiliki paradigma yang bertolak belakang. Paradigma bidang humas adalah mengontrol informasi yang akan disampaikan dan membentuk citra instansi yang diinginkan. Sedangkan paradigma pelayanan informasi publik adalah MALE (Maximum Access Limited Exemption), yakni memberikan informasi sebanyak-banyaknya dengan pengecualian yang terbatas dan tidak mutlak. Bersifat ketat artinya, pengecualian informasi dilakukan dengan pengujian seksama dengan mempertimbangkan berbagai aspek legal, kepatutan dan kepentingan umum. Bersifat terbatas artinya, alasan pengecualian hanya didasarkan pada 
ketentuan Pasal 17 UU KIP, dan dengan memperhatikan jangka waktu pengecualian informasi Informasi. Informasi yang telah dikecualikan dapat dinyatakan terbuka untuk melindungi kepentingan umum yang lebih besar.

Berdasarkan monitoring yang dilakuan KI Pusat terhadap Badan Publik sebagaimana terlampir dalam Lampiran I Peraturan Komisi Informasi Pusat No. 1 Tahun 2010, mayoritas Badan Publik belum melakukan langkah-langkah yang diamanatkan UU KIP seperti: (i) membuat peraturan internal mengenai pelaksanaan UU KIP; (ii) menunjuk PPID (Pejabat Pengelola Informasi dan Dokumentasi); dan (iii) menetapkan daftar informasi publik yang terbuka dan yang dikecualikan.

Badan Publik negara yang sudah membuat regulasi internal dan menunjuk PPID ada 22, antara lain Kementerian Komunikasi dan Informatika, Kementerian Hukum dan HAM, Kementerian Kehutanan, Kementerian Kebudayaan dan Pariwisata, DPR RI, DPD RI, Polri, Kementerian Koordinator Politik Hukum dan Keamanan, Arsip Nasional, Komisi Pemilihan Umum (KPU), Komisi Pemberantasan Korupsi (KPK), Kementerian Perhubungan, Kementerian Negara Pemberdayaan Perempuan dan Perlindungan Anak, Kementerian Koordinator Kesejahteraan Rakyat, Lembaga IImu Pengetahuan Indonesia (LIPI), Mahkamah Konstitusi, Kejaksaan Agung, Badan
Pengawasan Keuangan dan Pembangunan (BPKP), Kementerian Kesehatan, Kementerian Pendidikan Nasional, Kementerian Pekerjaan Umum, Kementerian Pendayagunaan Aparatur Negera dan Reformasi Birokrasi, Mahkamah Agung.

\section{Keterbukaan Informasi Publik Dalam Pemerintahan Terbuka (Open Government) Menuju Tata Pemerintahan Yang Baik (Good Governance)}

Hakekat pemerintahan adalah pelayanan kepada masyarakat. Pemerintahan adakarena kehendak rakyat. Untuk itu pemerintahan diadakan bukan untuk melayani dirinya sendiri, tetapi untuk melayani masyarakat serta menciptakan kondisiyang menginginkan setiap masyarakat mengembangkan kemampuan dan kreativitasnya demi mencapai tujuan bersama. ${ }^{14}$

Salah satu hak yang dimiliki masyarakat sesuai konstitusi UUD NRI 1945 adalah hak untuk memperoleh keterbukaan informasi publik. Pembahasan tentang keterbukaan informasi publik (public access to information) di dalam sistem negara yang demokratis (democratic state) selalu terkait dengan pemerintahan yang terbuka (open government) dan tata pemerintahan yang baik (good governance). Tiga konsep ini saling terkait satu sama lain, sebab segala bentuk turunan dari pemerintahan demokratis memang dimaksudkan untuk menjamin hak asasi manusia.

14 Ryaas Rasyid, Desentralisai Dalam Menunjang Pembangunan Daerah Dalam Pembangunan Administrasi Di Indonesia, (Jakarta: LP3ES), hal. 13. 


\section{$\mathrm{R}^{\text {juenal }}$ ECHSVINDING}

Good Governance mensyaratkan pemerintahan terbuka (open government) sebagai salah satu pondasinya. ${ }^{15}$ Kebebasan informasi (public access to information) merupakan salah satu prasyarat untuk menciptakan pemerintahan yang terbuka (open government). Pemerintahan terbuka adalah penyelenggaraan pemerintahan yang transparan, terbuka dan partisipatoris. ${ }^{16} \mathrm{Hal}$ ini mencakup seluruh proses pengelolaan sumber daya publik sejak dari proses pengambilan keputusan, pelaksanaan serta evaluasinya.

Pemerintahan yang terbuka mensyaratkan adanya jaminan atas 5 (lima) hal: ${ }^{17}$

a. Hak untuk memantau perilaku pejabat publik dalam menjalankan peran publiknya (right to obsverve);

b. Hak untuk memperoleh informasi (right to infomation);

c. Hak untuk terlibat dan berpartisipasi dalam proses pembentukan kebijakan publik (right to participate);

d. Kebebasan berekspresi yang salah satunya diwujudkan dalam kebebasan pers;

e. Hak untuk mengajukan keberatan terhadap penolakan atas hak-hak yang ditolak.

Dengan demikian hak publik untuk memperoleh informasi merupakan salah satu prasyarat penting untuk mewujudkan pemerintahan terbuka. Perwujudan pemerintahan terbuka dapat dilihat sebagai upaya untuk mencegah timbulnya praktekpraktek korupsi, kolusi dan nepotisme (KKN) dalam mengelola sumber daya publik. Hal ini menjadi pondasi utama dalam rangka mewujudkan tata pemerintahan yang baik (good governance).

Komitmen moral pemerintah merubah paradigma kekuasaan menjadi paradigma pelayanan publik dan adanya tata pemerintahan yang baik (good governance) menjadi prasyarat yang penting dalam menciptakan partisipasi masyarakat karena akan berhubungan langsung dengan kepentingan masyarakat sebagai konstituen politik dan lingkungan pelayanan birokrasi. Kepemerintahan yang baik (goodgovernance) mensyaratkan dalam penyelenggaraan pemerintahan, pembangunan, dan pelayanan publik tidak semata-mata didasarkan pada pemerintah (government) atau negara (state) saja, tapi harus melibatkan seluruh elemen, baik dalam intern birokrasi maupun di luar birokrasi publik (masyarakat) sehingga masyarakat dapat mengetahui apa saja yang telah dilakukan oleh pemerintah untuk mereka dan bagaimana pertanggungjawaban setiap kebijakan yang telah dijalankan.

Konsep governance mulai berkembang pada awal 1990-an ditandai dengan adanya cara pandang (point of view) yang baru terhadap peran pemerintah (government)

15 Mas Achmad Santosa, Good Governance dan Hukum Lingkungan, (Jakarta: Indonesian Center for Environmental Law (ICEL), 2001), Bab III.

Ibid.

17 Koalisi Untuk Kebebasan Informasi, Melawan Ketertutupan Informasi Menuju Pemerintahan Terbuka, Cetakan II, (Jakarta: USAID, 2003), hal. 18. 
dalam menjalankan sistem pemerintahan. United Nations Development Program mendefinisikan governance sebagai berikut: ${ }^{18}$

"Governance is the exercise of economic, political, and administrative authority to manage a country's affair at all levels and means by which states promote social cohesion, integration, and ensure the well being of their population".

("Kepemerintahan adalah pelaksanaan kewenangan di bidang ekonomi, politik, dan administrasi untuk mengelola berbagai urusan negara pada setiap tingkatan dan merupakan instrument kebijakan negara untuk mendorong terciptanyakepaduansosial, integrasi, dan menjamin kesejahteraan masyarakat").

Sedangkan kata "good" yang berarti "baik" dalam istilah kepemerintahan memiliki dua arti, yaitu:

a. Nilai-nilai yang menjunjung tinggi kehendak rakyat, dan nilai-nilai yang dapat meningkatkan kemampuan rakyat dalam pencapaian tujuan pembangunan nasional yang mandiri, berkelanjutan, dan berkeadilan sosial.

b. Aspek fungsional dari pemerintah yang efektif dan efisien dalam pelaksanaan tugasnya untuk mencapai tujuan nasional tersebut.

Paradigma penyelenggaraan pemerintahan telah terjadi pergeseran dari paradigma "Rule Government" yang menyandarkan pada peraturan perundang- undangan yang berlaku menjadi paradigma "Good Governance"dimanapenyelenggaraan negara yang solid dan bertanggung jawab, serta efisien dan efektif, dengan menjaga "kesinergian" interaksi yang konstruktif diantara domain-domain negara, sektor swasta dan masyarakat (society). ${ }^{19}$

UNDP sebagai institusi global yang sukses mengekspor paket good governance ke seluruh dunia, utamanya ke negaranegara dunia ketiga membagi 9 (sembilan) karakteristik good governance, sebagai berikut:20

a. Participation. Setiap warga negara mempunyai suara dalam pembuatan keputusan, baik secara langsung maupun melalui intermediasi institusi legitimasi yang mewakili kepentingannya;

b. Rule of Law. Kerangka hukum harus adil dan dilaksanakan tanpa pandang bulu, terutama Hukum dan HAM.

c. Transparancy. Transparansi di bangun atas dasar kebebasan arus informasi. Proses-proses, lembaga-lembaga dan informasi secara langsung dapat diterima oleh mereka yang membutuhkan. linformasi harus dapat dipahami dan dapat dimonitor.

d. Responsiveness. Lembaga-lembaga dan proses-proses harus mencoba untuk melayani setiap stakeholders.

e. ConcensusOrientation.Goodgovernance menjadi perantara kepentingan yang Instansi Pemerintah, LAN dan BPKP, 2000.

20 Dahlan Thaib, Transparansi dan Pertanggungjawaban Tindakan Pemerintah, disampaikan dalam Seminar Arah Pembangunan Hukum Menurut UUD 1945, diselenggarakan oleh BPHN, 2006, hal. 5-6. 
berbeda untuk memperoleh pilihan terbaik bagi kepentingan yang lebih luas, baik dalam hal kebijakan maupun prosedur-prosedur.

f. Equity. Semua warga negara, baik lakilaki maupun perempuan mempunyai kesempatan untuk meningkatkan atau menjaga kesejahteraan mereka.

g. Effectiveness \& Eficiency. Proses-proses dan lembaga-lembaga menghasilkan sesuai dengan apa yeng telah digariskan dengan menggunakan sumber-sumber yang tersedia sebaik mungkin.

h. Accountability. Para pembuat keputusan dalam pemerintahan, sektor swasta dan masyarakat (society) bertanggungjawab kepada publik dan lembaga-lembaga stakeholders. Akuntabilitasinitergantung pada organisasi dan sifat keputusan yang dibuat, apakah keputusan tersebut untuk kepentingan internal atau eksternal orgaisasi.

i. Strategic Vision. ${ }^{21}$ Para pemimpin dan publik harus mempunyai perspektif good governance dan pengembangan sumber daya manusia yang luas dan jauh ke depan sejalan dengan apa yang diperlukan untuk pembangunan semacam ini.

Jelas bahwa komponen ataupun prinsip yang melandasi tata pemerintahan yang baik sangat bervariasi dari satu institusi ke institusi lain, namun paling tidak terdapat sejumlah prinsip yang dianggap sebagai prinsip-prinsip utama yang melandasi good governance, yaitu (1) Akuntabilitas; (2) Transparansi; dan (3) Partisipasi Masyarakat. Ketiga prinsip ini tidak dapat berjalan sendiri-sendiri, terdapat hubungan yang sangat erat dan saling mempengaruhi dan ketiganya adalah instrumen yang diperlukan untuk mencapai manajemen publik yang baik.

\section{PRINSIP AKUNTABILITAS}

Akuntabilitas publik adalah prinsip yang menjamin bahwa setiap kegiatan penyelenggaraan pemerintahan dapat dipertanggungjawabkan secara terbuka oleh pelaku kepada pihak-pihak yang terkena dampak penerapan kebijakan. Dalam hubungannya dengan efektivitas pelaksanaan UU KIP, prinsip akuntabilitas ini memiliki 2 aspek yaitu komunikasi publik oleh pemerintah dan hak masyarakat terhadap akses informasi. Keduanya akan sulit dilakukan jika pemerintah tidak menangani dengan baik kinerjanya karena menajemen kinerja yang baik adalah titik awal dari transparansi.

\section{Prinsip Transparansi}

Transparansi adalah prinsip yang menjamin akses atau kebebasan bagi setiap orang untuk memperoleh informasi tentang penyelenggaraan pemerintahan, yakni informasi tentang kebijakan, proses pembuatan dan pelaksanaannya, serta hasil-hasil yang dicapai. Komunikasi publik menuntut usaha afirmatif dari pemerintah

21 Joko Widodo, Good Governance: Telaah dari dimensi Akuntabilitas dan Kontrol Birokrasi Pada Era Desentralisasi dan Otonomi Daerah, (Surabaya: Insan Cendekia) hal. 25-26. 
untuk membuka dan mendiseminasi informasi maupun aktivitasnya yang relevan. Transparansi harus seimbang dengan kebutuhanakankerahasiaanlembagamaupun informasi-informasi yang mempengaruhi hak privasi individu. Keterbukaan membawa konsekuensi adanya kontrol yang berlebihlebihan dari masyarakat dan bahkan oleh media massa. Karena itu, kewajiban akan keterbukaan harus diimbangi dengan nilai pembatasan, yang mencakup kriteria yang jelas dari Badan Publik tentang informasi apa saja yang akan diberikan dan pada siapa informasi tersebut diberikan.

Dalam UU KIP ketentuan tersebut diatur dalam BabIV, Pasal 10-16 untuk Informasiyang wajib disediakan dan diumumkan dan Bab V, Pasal 17 untuk informasi yang dikecualikan. Disini peran media menjadi sangat penting bagi transparansi pemerintah, baik sebagai sebuah kesempatan untuk berkomunikasi pada publik maupun menjelaskan berbagai informasi yang relevan sekaligus juga sebagai "watchdog" atas berbagai perilaku menyimpang dari aparat birokrasi.

Prinsip Transparansi paling tidak dapat di ukur melalui sebuah indikator seperti:

a. Mekanisme yang menjamin sistem keterbukaan dan standarisasi dari semua proses-proses pelayanan publik;

b. Mekanisme yang memfasilitasi pertanyaan-pertanyaan publik tentang berbagai kebijakan dan pelayanan publik maupun proses-proses di dalam sektor publik; c. Mekanismeyangmemfasilitasipelaporan maupun penyebaran informasi maupun penyimpangan tindakan aparat publik di dalam kegiatan melayani.

Keterbukaan pemerintah atas berbagai aspek pelayanan publik pada akhirnya akan membuat pemerintah menjadi bertanggung jawab kepada semua stakeholders yang berkepentingan dengan proses maupun kegiatan dalam sektor publik.

\section{Prinsip Patisipasif}

Partisipasi adalah prinsip bahwa setiap orang memiliki hak untuk terlibat dalam pengambilan keputusan di setiap penyelenggaraan pemerintahan. Partisipasi dibutuhkan dalam memperkuat demokrasi, meningkatkan kualitas dan efektivitas layanan publik. Setidak-tidaknya ada 2 (dua) alasan mengapa sistem partisipatoris dibutuhkan dalam negara demokratis. Pertama, bahwa sesungguhnya rakyat sendirilah yang paling paham mengenai kebutuhannya. Kedua, bermula dari kenyataan bahwa pemerintahan yang modern cenderung luas dan kompleks menjadikan birokrasi tumbuh membengkak di luar kendali. Oleh sebab itu untuk menghindari alienasi warga negara, maka para warga negara itu harus di rangsang dan di bantu dalam membina hubungan dengan aparat pemerintah. 


\section{E. Penutup}

\section{Kesimpulan}

a. UU KIP ini menghendaki tersedianya informasi secara lengkap, tersusun rapi, dan terpusat pada satu institusi badan informasi publik. Dengan demikian informasi yang dibutuhkan menjadi mudah di akses baik oleh pegawai pemerintah maupun masyarakat dan otomatis menghemat biaya dan mengefisienkan waktu kerja yang diperlukan ketika menelusuri dan mencari informasi yang sebelumnya terserak atau tidak tertata dengan baik. Hal ini selaras dengan beberapa asas dalam UU KIP, yaitu; Pertama, setiap informasi publik bersifat terbuka dan dapat di akses oleh setiap pengguna informasi publik. Kedua, informasi publik yang dikecualikan bersifat ketat dan terbatas. Ketiga, setiap informasi publik harus dapat diperoleh setiap pemohon informasi publik dengan cepat dan tepat waktu, biaya ringan, dan cara yang sederhana. Keempat, informasi publik yang dikecualikan bersifat rahasia sesuai undangundang, kepatuhan dan kepentingan umum, didasarkan pada pengujian tentang konsekuensi yang timbul apabila suatu informasi diberikan kepada masyarakat, serta setelah dipertimbangkan dengan seksama bahwa menutup informasi publik dapat melindungi kepentingan yang lebih besar daripada membukanya dan sebaliknya.

b. Lembaga pemerintah belum betulbetul siap mengimplementasikan UU KIP. Hal ini terlihat dari belum dilakukannya langkah-langkah yang diamanatkan UU KIP oleh mayoritas badan publik seperti: (i) membuat peraturan internal mengenai pelaksanaan UU KIP; (ii) menunjuk PPID (Pejabat Pengelola Informasi dan Dokumentasi); dan (iii) menetapkan daftar informasi publik yang terbuka dan yang dikecualikan. Meski pun demikian, ditemukan bahwa terdapat 22 lembaga publik yang sudah membuat regulasi internal dan menunjuk PPID, antara lain Kementerian Komunikasi dan Informatika, Kementerian Hukum dan HAM, Kementerian Kehutanan, Kementerian Kebudayaan dan Pariwisata, DPR RI, DPD RI, Polri, Kementerian Koordinator Politik Hukum dan Keamanan, Arsip Nasional, Komisi Pemilihan Umum (KPU), Komisi Pemberantasan Korupsi (KPK), Kementerian Perhubungan, Kementerian Negara Pemberdayaan Perempuan dan Perlindungan Anak, Kementerian Koordinator Kesejahteraan Rakyat, Lembaga Ilmu Pengetahuan Indonesia (LIPI), Mahkamah Konstitusi, Kejaksaan Agung, 


\section{R Eunen HTSVINDING}

Badan Pengawasan Keuangan dan Pembangunan (BPKP), Kementerian Kesehatan, Kementerian Pendidikan Nasional, Kementerian Pekerjaan Umum, Kementerian Pendayagunaan Aparatur Negera dan Reformasi Birokrasi, Mahkamah Agung.

c. Implementasi UU KIP terlihat dari hubungan antara pemerintah dan warganegaranya. Penerapan UU KIP melekat pada 2 (dua) pihak, yaitu penyelenggara pemerintahan dan masyarakat atau publik. Pada sisi penyelenggara pemerintahan, penerapan UU KIP antara lain menyediakan informasi publik, baik informasi yang sifatnya wajib, berkala, dan serta merta. Implementasi lainnya adalah bahwa segala kegiatan urusan tata kepemerintahan seperti kebijakan publik, pelayanan publik, pengadaan barang dan jasa pemerintah, penyusunan anggaran (DIPA) termasuk isi keputusan dan alasan pengambilan kebijakan publik harus terbuka dan dapat diakses oleh masyarakat.

\section{Saran}

a. Pemerintah perlu meningkatkan penerapan UU KIP agar partisipasi masyarakat terhadap kinerja penyelenggaraan pemerintahan semakin meningkat. b. Pemerintah perlu meningkatkan tanggung jawab dalam menjalankan tugas dan fungsinya sehingga tujuan menciptakan tata kelola pemerintahan yang transparan, akuntabel dan partisipasif dapat tercapai sesuai dengan prinsipprinsip good governance.

c. Pemerintah harus siap dan sungguh-sungguh dalam mengimplementasikan UU KIP ini, dengan menunjuk pejabat penyedia informasi publik (PPID) dalam sebagaimana diamanatkan PP Nomor 61 Tahun 2010 tentang pelaksanaan UU KIP, karena penunjukan PPID ini bersifat wajib (mandatory). 


\section{DAFTAR PUSTAKA}

Suranto, Hanif dan Agus Mulyono, Dari Lokal Mengepung Nasional, Dinamika Proses Legislasi Kebebasan Memperoleh Informasi Publik Di Indonesia, Cetakan Pertama, (Jakarta: Koalisi Untuk Kebebasan Informasi, 2007).

Widodo, Joko, Good Governance: Telaah dari dimensi Akuntabilitas dan Kontrol Birokrasi Pada Era Desentralisasi dan Otonomi Daerah, (Surabaya: Insan Cendekia)

Koalisi Untuk Kebebasan Informasi, Melawan Ketertutupan Informasi Menuju Pemerintahan Terbuka, Cetakan II, Jakarta, Tahun 2003.

Lembaga Administrasi Negara Republik Indonesia, Pedoman Penyusunan Pelaporan Akuntabilitas Kinerja Instansi Pemerintah, LAN dan BPKP, 2000.

Santosa, Mas Achmad, Good Governance dan Hukum Lingkungan, Indonesian Center for Environmental Law (ICEL), 2001.

Mandica-Nur, N.G.B., Panduan Keterbukaan Informasi Publik (KIP) Untuk Petugas Pengelola dan Pemberi Informasi di Badan Publik, IRDI dan USAID, Cetakan Pertama, 2009

Mandica-Nur, Notrida G.B., Panduan Keterbukaan Informasi Publik Untuk Petugas Pengelola dan Pemberi Informasi di Badan Publik, Penerbit IRDI-Kemenkominfo-USAID-DRSP, Cetakan Pertama, Jakarta, Tahun 2009.

Soekanto, Soerjono dan Sri Mamudji, Penelitian Hukum Normatif Suatu Tinjauan Singkat, (Jakarta: Rajawali Press, 1990).

Sedarmayanti, Good Governance, Kepemerintahan yang Baik, Bagian Dua, (Bandung: Mandar Maju, 2000).

Mamudji, Sri, dkk, Metode Penelitian dan Penulisan Hukum, (Jakarta: Badan Penerbit FH UI, 2005).

Rasyid, Ryaas, Dentralisai Dalam Menunjang Pembangunan Daerah Dalam Pembangunan Administrasi Di Indonesia, (Jakarta: LP3ES)

\section{A. Makalah-Makalah}

Ahmad M. Ramli, KIP dan Good Governance, Makalah disampaikan pada Seminar Sosialisasi UU KIP di Jakarta, Tahun 2009.

Dahlan Thaib, Transparansi dan Pertanggungjawaban Tindakan Pemerintah, disampaikan dalam

Seminar Arah Pembangunan Hukum Menurut UUD 1945, diselenggarakan oleh BPHN, 2006 Komisi Informasi, Laporan 1 Tahun Implementasi UU KIP, April Tahun 2011.

Usman Abdhali Watik, Implikasi UU Nomor 14 Tahun 2008 tentang Keterbukaan Informasi Publik terhadap Peningkatan Pelayanan Publik, Universitas Kristen Petra, Surabaya, 26 Juli 2010

Republik Indonesia, Undang-Undang Dasar Negara Republik Indonesia Tahun 1945 


\section{R Euknal HTSVINDING}

Republik Indonesia, Undang-Undang Nomor 14 Tahun 2008 tentang Keterbukaan Informasi Publik, ditetapkan di Jakarta tanggal 30 April 2008, Lembaran Negara RI Nomor 61, tahun 2008 dan Tambahan Lembaran Negara RI Nomor 4846 Tahun 2008.

Republik Indonesia, Peraturan Pemerintah Nomor 61 Tahun 2010 tentang Pelaksanaan UndangUndang Nomor 14 Tahun 2008 tentang Keterbukaan Informasi publik, ditetapkan di Jakarta tanggal 20 Agustus 2010, Lembaran Negara RI Nomor 99 Tahun 2010.

Republik Indonesia, Peraturan Komisi Informasi Nomor 1 Tahun 2010 tentang Standar Layanan Informasi Publik, ditetapkan di Jakarta tanggal 30 April 2010, Lembaran Negara RI Nomor 272 Tahun 2010.

Republik Indonesia, Peraturan Komisi Informasi Nomor 2 Tahun 2010 tentang Prosedur Penyelesaian Sengketa Informasi Publik, ditetapkan di Jakarta tanggal 20 Agustus 2010. 